\title{
The Role of Mining in National Economies
}

\author{
Ioana DORIN ${ }^{1}$ \\ Cristina DIACONESCU ${ }^{2}$ \\ Dan loan TOPOR ${ }^{3}$
}

${ }^{1} 1$ Decembrie 1918 University, Alba-Iulia, ${ }^{1}$ E-mail: doris.ioana@yahoo.com

${ }^{2}$ Oltenia Energetic Complex, ${ }^{2}$ E-mail: dcristina77@yahoo.com

${ }^{3}$ Hyperion University, Bucharest, ${ }^{3}$ E-mail: dan.topor@yahoo.com

\begin{abstract}
Dual perspective on the industry makes the approach of industrial activities be different at the world countries level, depending on the ability of each system to accept, to take necessary measures and solve the problems caused by industry. Under pressure triggered by different types of actions, the industry has managed to maintain and even to impose itself in certain areas, despite the fact that the restriction or elimination of certain industries are dominant. The mining industry is a very important force in the global economy, occupying a primary position in the supply chain of resources. Despite this, its role varies and differs greatly, at national level from an economy to another, and it is not properly documented and sometimes even incomprehensible.
\end{abstract}

Key words Mining industry, industrial conversion, industrial reconversion, production, mining project, investments, exports

\section{Introduction}

The industry is an economic sector with different meanings for contemporary society.

On the one hand, it provides polarization of territorial resources respectively supporting the short and long-term welfare and different economic systems, on the other hand, it generates, socio-economic and environmental breakdowns.

To this context, conversion and reconversion of industry in many countries represent a natural evolution, whether their economy is considered stable or on the contrary - very dynamic.

The issues, generating such state of facts are mainly the following:

- The productivity decreasing of industrial activities generated by various causes (poor management, competition etc.);

- Exhaustion of local resources (energy, raw materials, human factors, degradation of infrastructure etc.);

- Territorial dynamics making the industrial spaces to have an inappropriate position in the urban context of our times, becoming increasingly sensitive;

- Civil society's pressure and local, national and regional administration, who want to avoid dissatisfactions and social unrests;

- Need for space to achieve the level of other categories of urban facilities.

Conversion and reconversion of industrial activities

In many cases, conversion and reconversion of industrial activities has been done inadvertently, a fact that allowed to be transferred to many of the problems inherited from the industrial phase a number of new features. 
The main challenges to be solved by conversion and industrial reconversion processes are physical, chemical and biological soil contamination, social tensions, poverty, budgetary deficit resulting from the loss of productive activities etc. (Table 1 ).

Table 1. Advantages and disadvantages characteristic of industrialization and post - industrialization periods

\begin{tabular}{|c|c|}
\hline \multicolumn{2}{|c|}{ Industrialization } \\
\hline Advantages & Disadvantages \\
\hline $\begin{array}{l}\text { - resource polarization } \\
\text { - increase in consumption } \\
\text { - life quality improving } \\
\text { - high level of employment } \\
\text { - increase in attractiveness }\end{array}$ & $\begin{array}{l}\text { - high consumption of resources and energy } \\
\text { - environmental degradation } \\
\text { - reliance of activities } \\
\text { - urbanization } \\
\text { - unprofitable models }\end{array}$ \\
\hline \multicolumn{2}{|l|}{ The post - industrialization period } \\
\hline Advantages & Disadvantages \\
\hline $\begin{array}{l}\text { - space rebalancing by adapting to the territorial potential } \\
\text { - functional reconversion opportunities offered by } \\
\text { industrial sites } \\
\text { - easy access to multiple facilities } \\
\text { - improve the environment and hence the quality of life; }\end{array}$ & $\begin{array}{l}\text { - insecurity } \\
\text { - depopulation } \\
\text { - Management of complex environmental issues, especially } \\
\text { if contaminated sites } \\
\text { - Significant costs for professional reconversion and } \\
\text { restoring the occupational health } \\
\text { - Social tensions }\end{array}$ \\
\hline
\end{tabular}

Source: Based on I., Ioja C., Gavrilidis A., Cercleux L., Niță M., Vânău G. (2012), Perception of the Industrial Areas Conversion in Romanian Cities-Indicator of Human Settlements Sustainability, 48th ISOCARP Congress 2012, p. 2.

Perception of local government and population towards this process is a key element, as they are the beneficiaries of future urban insertions, whether they are of public utilities nature (green spaces, commercial spaces, different objectives of buildings, etc.) or limited to use by certain groups of beneficiaries (individual or collective residential complexes, business parks, industrial parks etc.).

\section{Mining role in the economy}

The mining industry is a very important force in the global economy, occupying a primary position in the supply chain resources. Despite this fact, its role varies and greatly differs at national level from an economy to another, and it is not properly documented and sometimes even incomprehensible.

In 2010, the nominal value of minerals global production was nearly four times higher than the one recorded in 2002 (Figure 1). This actually highlights the fact, that during this period, the increase in nominal value was significantly higher, than the gross domestic product of many countries throughout the world. This unprecedented growth was driven mainly by China, India and other emerging economies, and were linked to an associated sharp increase of raw materials' prices. Unlike this situation, in the previous decade (19922002), there were no nominal growths, but rather a reduction in real terms of inflation-adjusted.

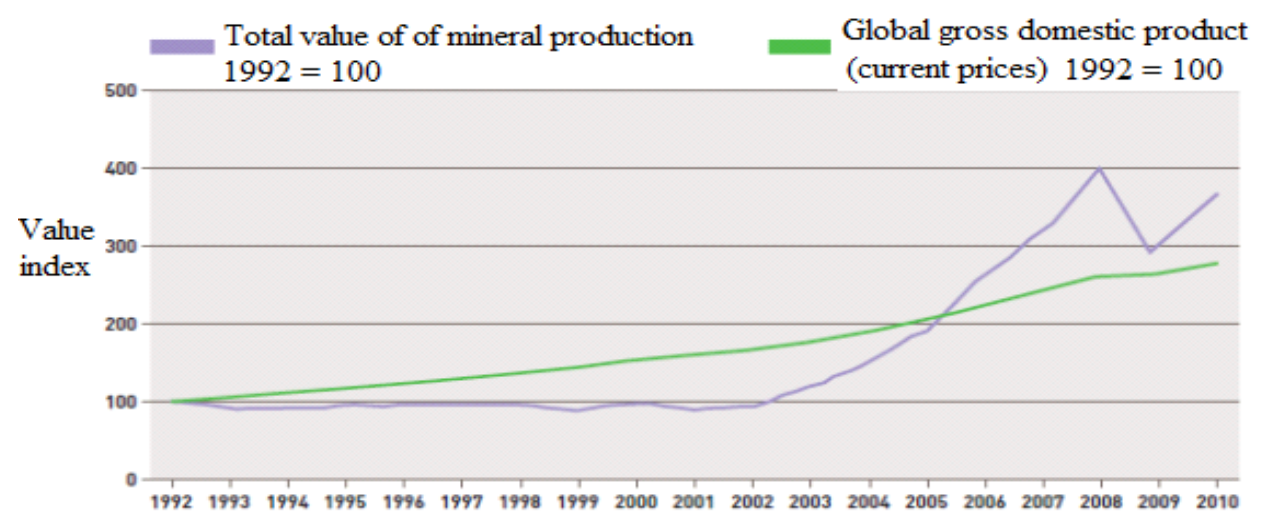

Source: The World Bank

Figure 1. Gross domestic product, globally and mineral production (1992-2010) 


\section{Economic benefits generated by mining}

Most of the countries with low or middle national income and the main areas, where mining brings significant direct economic benefits, are shown schematically in Figure 2.

The top line proves that the largest benefit, the mining offers to these national economies, is not their said income, but rather the contribution of foreign direct investments (up to $90 \%$ ).

It must be also pointed out that the first four segments (foreign direct investment, exports, government taxes and national income, measured in terms of GDP are benefits conferred by the mining industry to national governments.

The only employment, the smallest contribution represents a direct benefit of local communities.

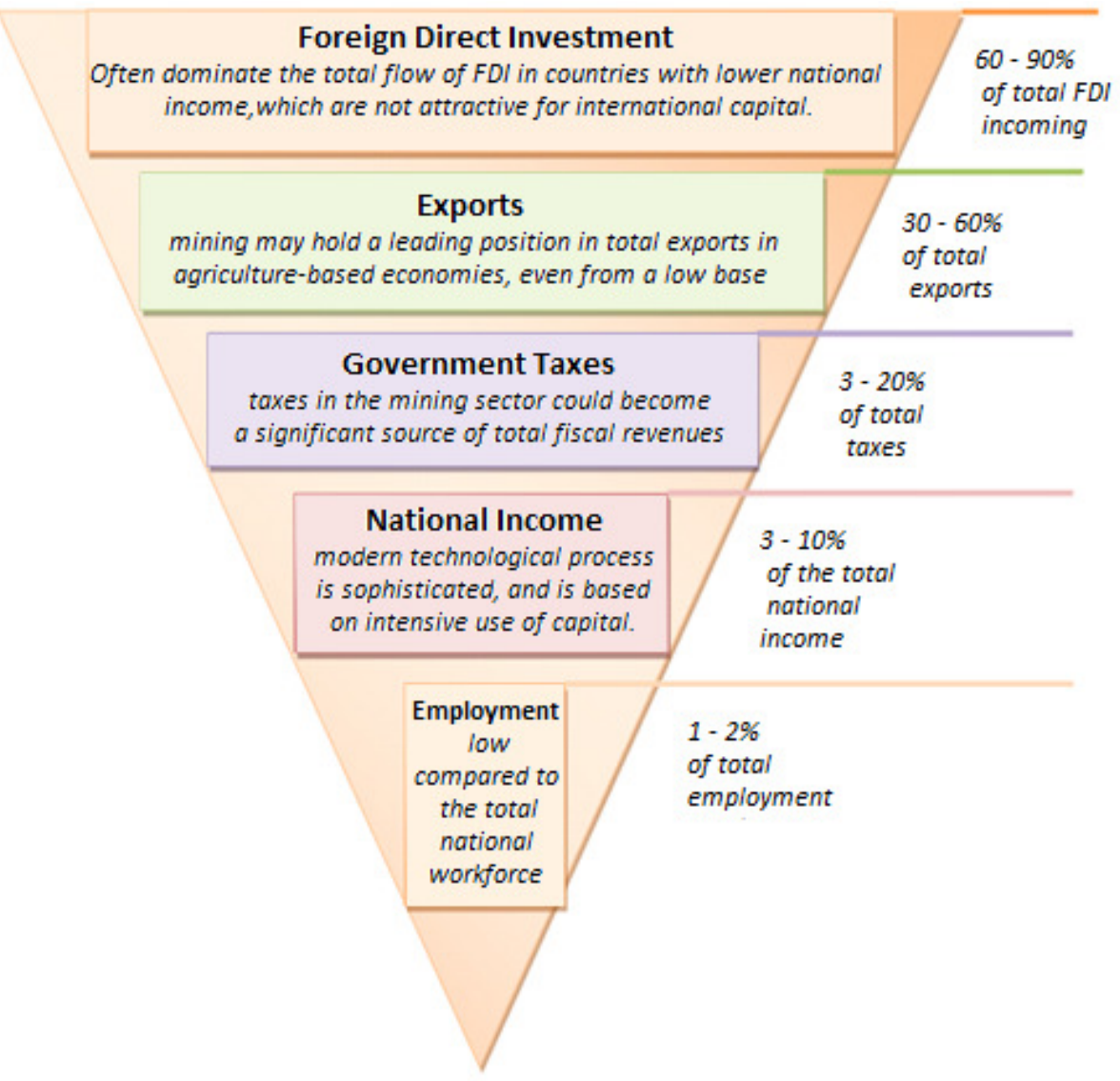

Source: ICMM

Figure 2. Macroeconomic contributions of mining in national economies with low or middle incomes

\subsection{Foreign direct investments (ISD)}

In most cases, the contribution of the mining industry of the country on total FDI is very high, usually more than half of the total annual FDI. This contribution is significant, especially in low-income countries, highlighting their ability to attract investment in mining, even when other sectors that attract FDI - sites seem unattractive. Contemporary realities also highlights that FDI - sites, in the mining sector, combined with increased financial benefits resulting from exchange rate can be a good catalyst for countries in order to improve the credit ratings and the capacity to draw long-term loans, financed from abroad.

However, there are some significant exceptions disapproving this model. Brazil, for example, is one of the world's countries who experienced the most successful emerging economies in terms of attracting FDI (they exceed 50 billion dollars in recent years). Notwithstanding this fact, the FDI's attracted by mining sector represents a very small share of total incoming FDI's received by Brazil, because, on the one hand, the 
economy is highly diversified, and on the other hand, a significant proportion of investment in mining industry is imputable to internal investments made by the Vale company, the largest mining company in Brazil.

Mining has a very important contribution to the total national investments, especially when mining is built starting from a lower economic base. For Brazil, only the investments of Vale Company represent the equivalent of about $5 \%$ of total annual national investments.

\subsection{Exports}

Modern reality confirms that mining has a great contribution to the exports of many countries. The mining sector generates significant gains from the exchange rate differences.

Most of the gains come into the national economy circuit being used by mining companies to import goods and services necessary for the organization and operation of mines.

The expert studies points out the significant contribution of net currency in the operational phase, even when the imports are barely contracted. During the phase of mines' organization, imports went usually high, as they are supported almost entirely by foreign capital flows and international credits.

\subsection{Government taxes}

Substantial differences between countries can be highlighted, as regards the contribution of mining to the total government revenue and the allocation of these revenues between the national and sub-national levels. However, the big picture on long-term of the mining industry contribution to income taxation (as well as other dimensions of macro-economic contribution of mining) must be considered.

In each case, the tax contribution of the mining projects shall not be recorded until the launch of a mining project, which is supported entirely by the companies in the sector, who actually pay these taxes. Usually this is due to the long duration elapsed, until the effective operation and accelerated capital reduction, often used to stimulate investment. A number of studies highlight the fact that mining taxes collected by governments rose sharply, as share on total budgeting revenues, after about seven to eight years from the initiation of major mining activities.

In this respect it seemed interesting to highlight the complete life cycle of a mining project on a hypothetical example referring to a discovery of the 1950s, developed in the 1960s, operated for 20-30 years until the mid-1990s and then closed (Figure 3).

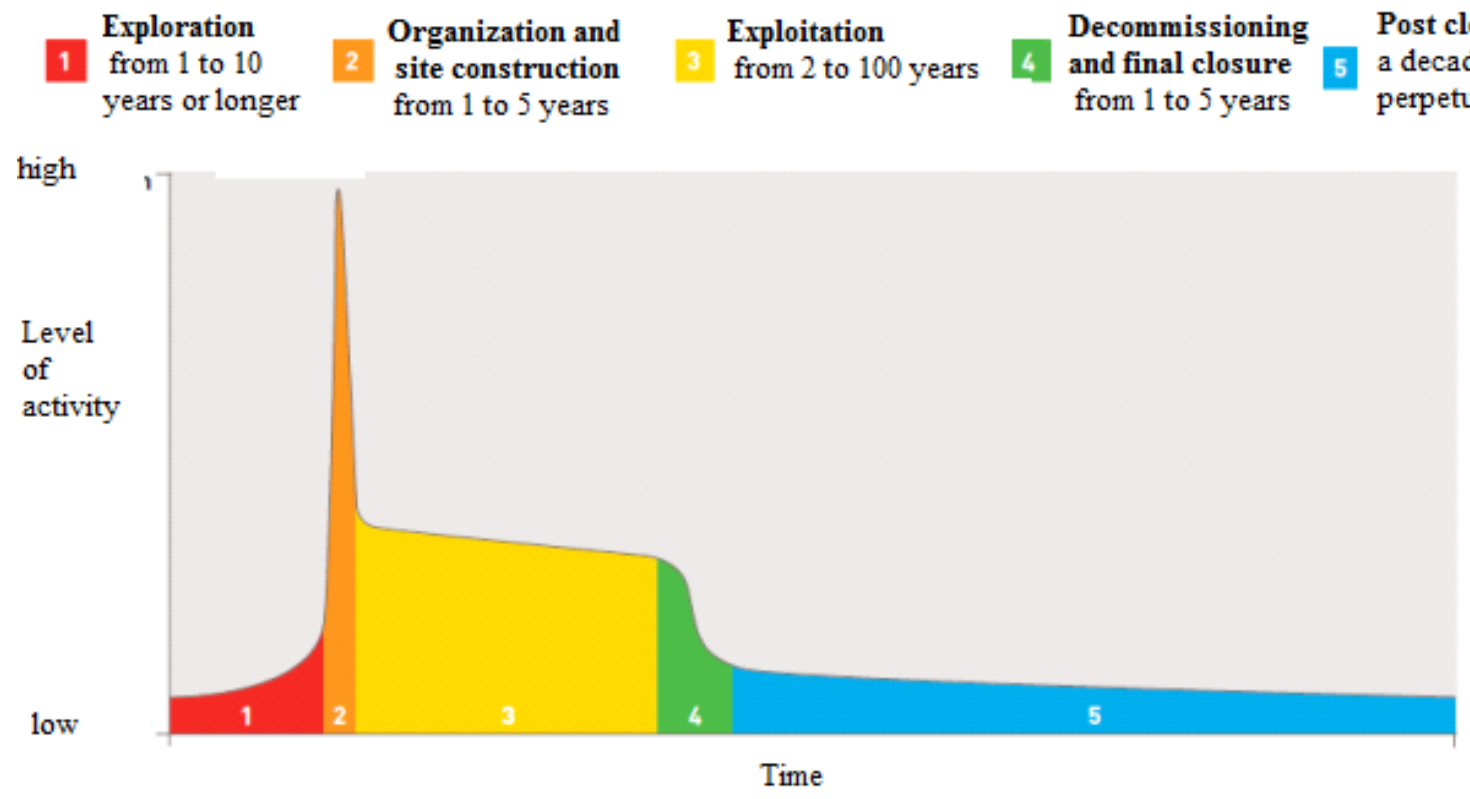

Source: ICMM

Figure 3. Life Cycle of a mining project 


\subsection{National income and gross domestic product}

It is generally considered that mining industry typically provide only a modest direct contribution to GDP of a country and to various components of national income (usually about $2-4 \%$ of national income). This rather low contribution is partially explained by the fact that emerging host countries are often deprived of a strong industrial supply, respectively of sophisticated mining technologies used in modern mines. Therefore, many of the upstream value added components (for ex. contribution to GDP), such as benefits of exploitation are transferred outside the host country. However, in the mature industrial economies (Romania and Brazil, for example), the GDP multiplication effects can be significant - one U.S. dollar in mining sector activity can generate three U.S. dollars or more in the economic activity, elsewhere. If this happens, the total contribution of the mining industry to GDP (direct and indirect) is much larger than the typical of $2-4 \%$.

\subsection{Employment and salaries}

New jobs created directly by large mining companies are usually well paid compared to national average salary on the economy. Unfortunately, the number of these jobs is quite small, rarely reaching the level of $1.5 \%$ of the total jobs, nationwide.

However, mining can have a successful role in generating indirect jobs in the supply chain. Such activity has multiplication effects that can often be very high. One employee of a mining company, usually correspond three or four employees from a different sector. In poor regions, where mining activity is dominant, indirect employment effects may be particularly important.

\section{Components of mining production value}

A larger integration of mining activities through various forms of connection confers the promise of mining contribution increasing within national economies, at each stage of the value chain.

The significance and nature of these contributions, however, vary depending on specific circumstances. For example, in many poor countries lack of quality suppliers determines mining companies to buy on the domestic market.

Table 2 shows the main elements of the production value, their components, as well as some of the key-determinants of the mining benefits for national economies.

Table 2. The main components of production value

\begin{tabular}{|c|c|c|}
\hline $\begin{array}{l}\text { The main components of } \\
\text { production value }\end{array}$ & Examples & $\begin{array}{l}\text { Key factors determining contribution to the national } \\
\text { economy }\end{array}$ \\
\hline 1. Operating costs & $\begin{array}{l}\text { Supplies (fuel, power, reactive, } \\
\text { water, transport); labour }\end{array}$ & $\begin{array}{l}\text { Availability of capacity for local bidding; } \\
\text { infrastructure, business environment, industrial policy }\end{array}$ \\
\hline 2. Salaries & $\begin{array}{l}\text { After taxes and mandatory } \\
\text { contributions, net salaries }\end{array}$ & $\begin{array}{l}\text { Achieving education locally, } \\
\text { availability of appropriate skills, educational policy }\end{array}$ \\
\hline $\begin{array}{lr}\text { 3. Capital } & \text { expenditure } \\
\text { (investments } & \text { and } \\
\text { depreciation) } & \end{array}$ & Machinery and equipment & $\begin{array}{l}\text { The development of the industrial base of the host } \\
\text { country }\end{array}$ \\
\hline 4. Taxes & $\begin{array}{l}\text { Royalties, corporate tax, } \\
\text { income tax }\end{array}$ & $\begin{array}{l}\text { Fiscal regime, incomes distribution, transparency, of } \\
\text { financial management, of the public sector } \\
\text { (expenditures). }\end{array}$ \\
\hline 5. Financing costs & $\begin{array}{l}\text { Interest on short-term and/or } \\
\text { long loans }\end{array}$ & Domestic financial sector development \\
\hline 6. The shareholders' profit & $\begin{array}{l}\text { Dividends (both private and } \\
\text { public authorities) }\end{array}$ & National ownership of the mining sector \\
\hline
\end{tabular}

Source: Own systematization 
Production value components represent a very important guide on the potential economic benefits that mining industry could generate for the national economy.

Components in rows 1 and 2 are the areas where mining industry contributes directly to economic development. Operating costs of companies of the sector reflect actually the local suppliers' revenues that contribute to the national GDP, especially where these mining inputs are made internally (row 1 ).

The salaries of workers represent a direct contribution to the country's GDP (row 2), divided between household incomes - salary revenues and withholding taxes.

The profits of mining companies (row 6) and taxes generated by companies (line 4) are an additional contribution to the GDP of the country

If the company has foreign capital, some of the profits may be repatriated, in which case an assessment of the contribution of the mining industry to gross national income (GNI) can be captured more accurately than in the GDP context.

\section{Conclusions}

From the literature review we concluded that there is no economic study group - either within the World Bank or the International Monetary Fund - to systematically capture the crucial role of extraction and mining production in the economies of every country in the world.

A deeper understanding of the various components of the mining industry in terms of production value, may help to illustrate the main types of benefits, this sector can generate, but also to identify how these benefits can be raised, respectively how the policy options aims to ensure local economic growth in the context of mining activities.

The amount of the contribution depends on the overall mining output and payments made for inputs, including financial capital, equipment, land and labour. As compensation for these inputs, mining companies pay suppliers for goods and services, workers' salaries and interest on loans. Also, companies must pay the shareholders (whether foreign or domestic) for a risk-adjusted minimum yield in the form of dividends or capital gains - to reward mining investments in risky assets on long term. The overplus remaining after all these inputs were rewarded is considered annuity of mineral resources. Broadly speaking, these annuities are allocated between the host government and the investing company in a manner depending of the host country's tax regime.

\section{References}

1. Căpuşneanu S., (Rakos) Boca I.S., Barbu C.M., Rof L.M., Topor D. (2013). Implementation of ActivityBased Budgeting method in the economic entities from mining industry of Romania", International Journal of Academic Research in Accounting, Finance and Management Sciences, Vol. 3. Issue 1, pp. 26-34.

2. Henderson J.V., Thisse J.F. (2004). Handbook of regional and urban economics, Elsevier Press, Amsterdam

3. Iojă C. (2008). Metode şi tehnici de evaluare a calității mediului în aria metropolitană a municipiului Bucureşti, Editura Universității din Bucureşti, Bucureşti.

4. Saghin I., Gavrilidis A., lojă C. (2011). Urban Regeneration through Industrial Restructuring of Brownfields in the Local Economies of Post Communist Countries. Case Study: Romania, The 47th ISOCARP Congress 2011, Wuhan, ISOCARP

5. Saghin I., Ioja C., Gavrilidis A., Cercleux L., Niță M., Vânău G. (2012). Perception of the Industrial Areas Conversion in Romanian Cities-Indicator of Human Settlements Sustainability, 48th ISOCARP Congress 2012.

6. ${ }^{* * *}$ The Global Methane Initiative, Country overview, https://www.globalmethane.org/documents/ toolsres coal overview ch29.pdf

7. ${ }^{* * *} \mathrm{CIMA}, \mathrm{http}: / /$ www.cimaglobal.com/About-us/What-is-management-accounting/

8. ${ }^{* * *}$ http://www.minind.ro/resurse minerale/Strategia Industriei_Miniere 2012 2035.pdf 